\title{
Factors Affecting the Demand for Milk and Dairy Products in the Slovak Republic
}

\author{
Lubica Kubicová, Kristína Predanocyová, Zdenka Kádeková
}

Department of Marketing and Trade Slovak, Faculty of Economics and Management, University of Agriculture in Nitra, Slovakia

\begin{abstract}
Paper is aimed at dairy sector in the Slovak Republic with an emphasis on identifying the determinants causing low demand for milk and dairy products. The primary objective is to identify consumer behavior and the main factors affecting consumer choices in choosing milk and dairy products. The primary source of information is created by the results of consumer survey proving the consumption of milk and dairy products is widespread among consumers, with cheese and yoghurt as the most preferred ones. The results of the consumer survey were confronted with a survey aimed at identifying the views of producers and processors of milk and dairy products. We identified the main issues, particularly the low redemption price of milk, lack of milk consumption and the absence of sales support.
\end{abstract}

\section{Keywords}

Milk and dairy products, consumption, factors affecting demand, consumer behavior.

Kubicová, L', Predanocyová, K. and Kádeková, Z. (2019) "Factors Affecting the Demand for Milk and Dairy Products in the Slovak Republic", AGRIS on-line Papers in Economics and Informatics, Vol. 11, No. 4, pp. 39-47. ISSN 1804-1930. DOI 10.7160/aol.2019.110404.

\section{Introduction}

Milk and dairy products take an irreplaceable place in everyday food consumption (Nicklas, 2009). Milk consumption has a positive impact on human health, growth and development of the human body (Košičiarová et al., 2017), strengthening of cognitive processes, health protection and prevention of various diseases (The Dairy Council, 2014). Despite the positive effects, it is necessary to solve the problem due to their inadequate consumption, which has been below the recommended intake in recent years (Nagyová et al., 2016). However, an individual satisfaction in food consumption depends more on the social and institutional context (Cecchini et al., 2018). The EU exports approximately $12 \%$ of its dairy production in the form of various dairy products (Mach et al., 2018), but the import of agricultural and food products does not regard only the domestic demand (Smutka et al., 2016). The aim of the paper is to examine the consumption of milk and dairy products in Slovakia and the factors determining buying and consumer behavior.

In Slovakia, the development of consumption of milk and dairy products per capita was accompanied by a fluctuating trend in the period
1997-2017. At present, the consumption of milk and dairy products is $176.1 \mathrm{~kg}$ per capita, which represents lower consumption by $20.0 \%$ compared to the recommended intake. Development of consumption of milk is not proportional to the total consumption of milk and dairy products in the analyzed period 1997-2017 (Figure 1). In the first reference year, consumption was $75.8 \mathrm{~kg}$ per capita and in 2017 only $46.3 \mathrm{~kg}$. Consumption of drinking milk does not cover the recommended intake and falls by almost 50\%. Low milk consumption contributes to increasing milk prices and to constantly expanding supply of other dairy products such as cheese and yoghurts (Kubicová and Habánová, 2012).

The consumption of cheese is directly proportional to the total milk and dairy consumption. In the monitored period, a gradual increase in the consumption of cheese was recorded (Figure 2). In 1997, consumption was $6.3 \mathrm{~kg}$ and in the last analyzed year up to $11 \mathrm{~kg}$, which represented an increase in consumption by $74.6 \%$.

Consumption of sour-milk products is similar to consumption of cheese. In the analyzed period 1997-2017 there was a gradual increase in the intake of sour-milk products by Slovak consumers (Figure 3). In connection with mentioned, it is 


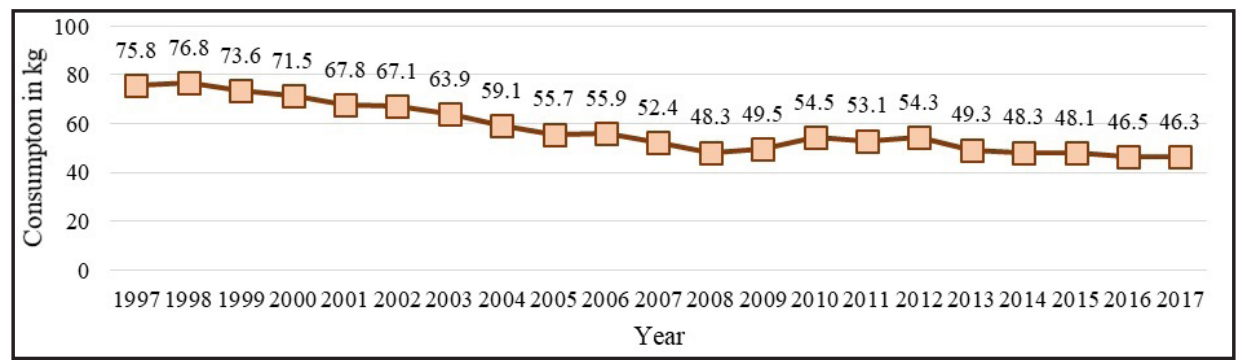

Source: own processing according to SO SR, 2018

Figure 1: Average Consumption of Drinking Milk in kg per Inhabitant of the Slovak Republic.

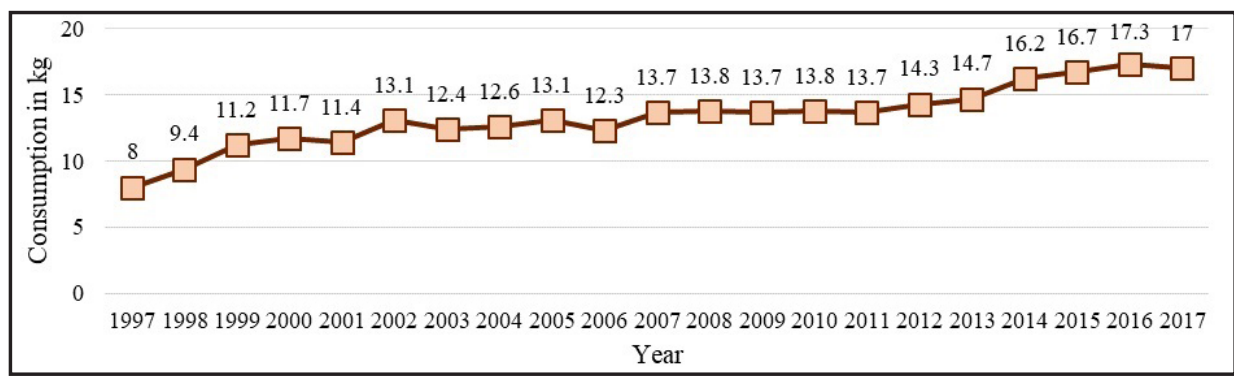

Source: own processing according to SO SR, 2018

Figure 2: Average Consumption of Cheese in kg per Inhabitant of the Slovak Republic.

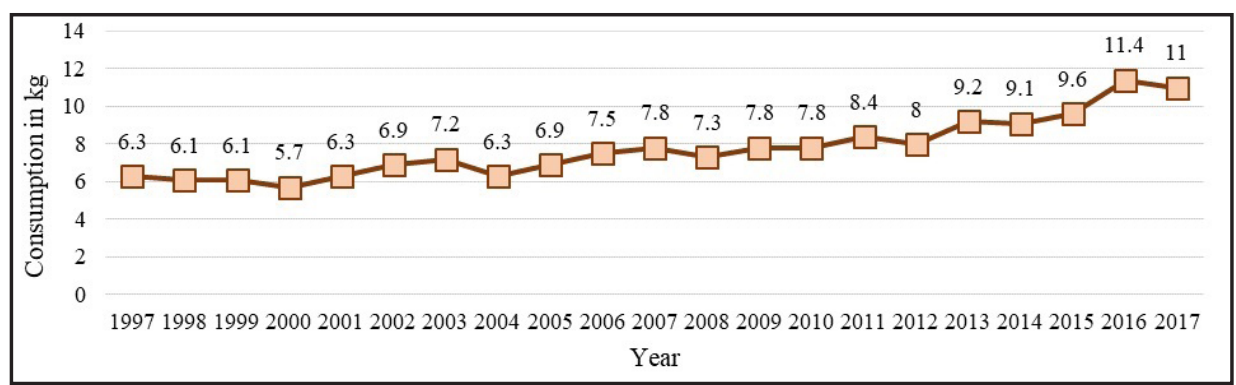

Source: own processing according to SO SR, 2018

Figure 3: Average Consumption of Sour-Milk Products in kg per Inhabitant of the Slovak Republic .

important to highlight the favorable consumption growth of $212.5 \%$ from $8.0 \mathrm{~kg}$ in 1997 to $17 \mathrm{~kg}$ in the last reference year. Kubicová and Dobák (2012) emphasize that the increase in consumption of sour-milk products was mainly determined by the increased and varied range of products of domestic and foreign production associated with marketing communication and a wider range of price levels.

Demand for milk and dairy products, is relatively low and is influenced by a large number of factors. Influencing factors are the level of retail prices in relation to the average income of the population the gross domestic product and its distribution among the population, the standard of living, the structure of the market, the intensity of international trade or the individual consumer behavior (Matošková and Gálik, 2016), the gross domestic product and its distribution among the population, the standard of living, the structure of the market, the intensity of international trade or the individual consumer behavior (Skořepa, 2009; Namiotko and Baleženti, 2017). Consumer behavior can be considered as one of the main factors determining the consumption of milk and dairy products (Polakevičová, 2015). Its essence lies in the search, purchase and consumption of selected foods, which satisfy the basic physiological needs of each consumer (Horská et al., 2009; Fogarassy et al., 2018). The article focuses on demand factors for the consumption of milk and dairy products, but one cannot ignore the role of retails and their influence on shaping this demand, e.g. through innovation (Ćuzović et al., 2017; Śmigielska and Stefańska, 2017).

\section{Materials and methods}

The aim of the paper is to point out the consumption of milk and dairy products in Slovakia, 
with an emphasis on the identification of factors related to consumer behavior. This goal was achieved by processing secondary data from the Statistical Office of the Slovak Republic (SO SR) and primary data which were obtained through consumer survey and survey of dairy producers and processors.

The questionnaire survey was conducted on a sample of 516 respondents in Slovakia and was implemented in an electronic version from April to December 2018. Respondents participating in the survey were diversified into 9 categories, by gender (women $64.1 \%$, males $35.9 \%$ ), age (up to 25 years $43.0 \%, 26-35$ years $23.3 \%$, $36-50$ years $19.2 \%, 51-60$ years $8.5 \%$, more than 61 years $6.0 \%$ ), residence (countryside $48.6 \%$, city 51.4 ) and monthly household income (less than 1,000 Eur $19.8 \%, 1,001-2,000$ Eur $54.7 \%$, 2,001-3,500 Eur 23.1\%, 3,501-4,500 Eur 2.1\%, more than 4,501 Eur $0.4 \%$ ).

The survey focused on milk and dairy producers and processors was carried out between October and December 2018 by personal and e-mail communications and was attended by 23 companies from Slovakia. Business entities were divided according to legal form of business (cooperative $43.5 \%$, joint stock company $21.7 \%$, limited liability company $13 \%$, self-employed farmer $13 \%$, self-employed person $8.7 \%$ ), enterprise size (micro enterprise $30.4 \%$, small enterprise $21.7 \%$, medium enterprise $47.8 \%$ ) and type of produced milk (cow milk $91.3 \%$, sheep milk $26.1 \%$, goat milk $8.7 \%$ ).

For a deeper analysis of the research objectives, the following hypotheses were formulated:

Hypothesis 1: We expect that consumers assess the importance of the individual criteria for choosing milk and dairy products differently.

Hypothesis 2: We expect that there is a dependency between average monthly expenditure on milk and dairy products per household member and the average monthly household income.

The formulated hypotheses were tested by applying the following statistical tests:

- Chi-square test for independence of two variables was used a cross classification table to examine the nature of the relationship between these variables. This statistical test assumes that there is no relationship between the two variables (Hypothesis 0). The alternative hypothesis states that there is some relationship between the two variables (Hypothesis 1).

$$
\begin{aligned}
& \chi^{2}=\sum_{i=1}^{r} \sum_{j=1}^{c} \frac{\left(O_{i, j}-E_{i, j}\right)^{2}}{E_{i, j}} \\
& r-\text { count of rows } \\
& c-\text { count of columns } \\
& O_{i, j}-\text { observed numbers of cases } \\
& E_{i, j} \text { - expected numbers of cases }
\end{aligned}
$$

- Cramer's coefficient was used to examine the power of correlations

$$
V=\sqrt{\frac{x^{2}}{n \cdot h}} \quad h=\min ((m-1),(k-1))
$$

$\chi^{2}-$ calculated test criterion

$n$ - count of observations

- Friedman test as the non-parametric alternative to the one-way ANOVA with repeated measures was used to test for differences between groups when the dependent variable being measured is ordinal. It can also be used for continuous data that has violated the assumptions necessary to run the one-way ANOVA with repeated measures (e.g., data that has marked deviations from normality).

$$
F=\left(\frac{12}{n \cdot k \cdot(k+1)} \sum_{j=1}^{k} R_{j}^{2}\right)-3 \cdot n \cdot k(k+1)
$$

- Nemeny's method was used to determine which random selections from the pooled random selection differ considerably provided that all selections are of the same range (Matejková et al., 2013; Stehlíková, 2005)

All the above-mentioned tests have been calculated in statistical software XL Stat. In hypothesis testing, if the p-value is lower than significant level 0.05 , the null hypothesis is rejected, and the alternative hypothesis is confirmed.

\section{Results and discussion}

The results of the consumer survey (Figure 4) proved that the respondents purchased all kinds of dairy products, with milk and cheese as the most preferred ones. This is confirmed by the fact that milk (56.4\%), cheese $(57.0 \%)$, butter $(51.7 \%)$ and yogurt $(51.4 \%)$ are most commonly bought and consumed by consumers in regular intervals. Kubelaková and Šugrová (2017) have come to similar conclusions, that 


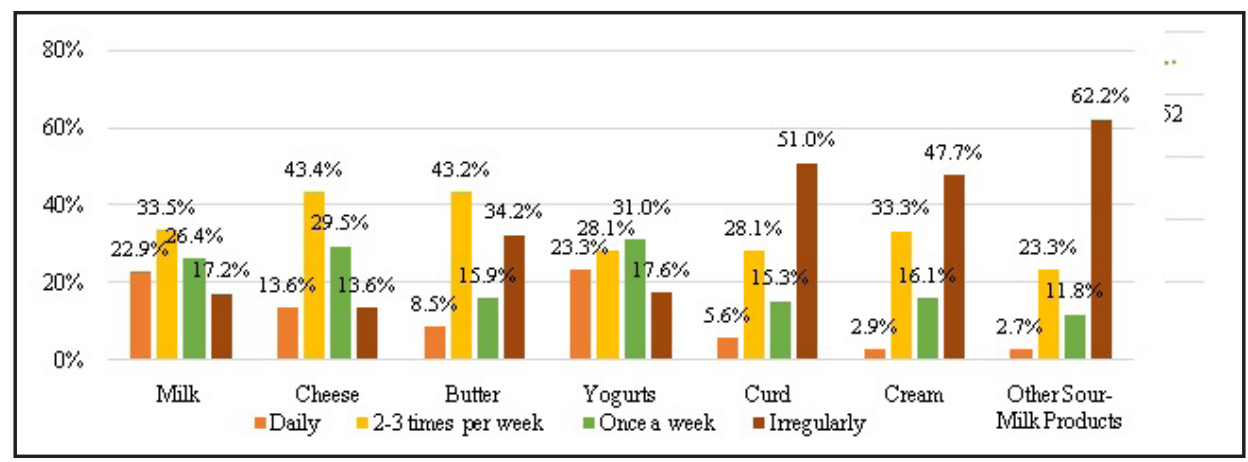

Source: Questionnaire survey, 2018

Figure 4: Types of Purchased Milk and Dairy Products.

more than $50 \%$ of consumers buy milk and dairy products more than once a week. Kapsdorferová and Nagyová (2005) identified milk, yoghurt and cheese as the most commonly preferred dairy food among consumers. On the other hand, other sour-milk products are least preferred, which was confirmed by their purchase by $70 \%$ of respondents in irregular intervals, followed by curd $(66.3 \%)$ and cream $(63.8 \%)$.

The survey was oriented where consumers most often buy milk and dairy products. Results showed that these products are most commonly purchased by consumers in supermarkets and hypermarkets (81.6\%), local stores (14.0\%), specialized stores $(2.1 \%)$ and directly from producers $(2.1 \%)$. However, some consumers start with livestock farming and produce their own milk (0.2\%). It follows that livestock farming and the subsequent dairy production in the domestic environment may in the future become an increasingly popular alternative for households to provide quality fresh milk and dairy products.

The questionnaire survey was also geared towards the factors that consumers influence when purchasing the analyzed foods. Based on the results (Figure 5) it can be concluded that quality (98.8\%), price $(91.4 \%)$, composition $(90.3 \%)$, durability $(89.3 \%)$ and nutrition data $(79.1 \%)$ are the most important factors for consumers. Kumar and Babu (2014) confirm our results and identify quality and price as the main factors determining the purchase of milk and dairy products. The GfK survey (2017) has shown that for the Slovak consumer is a very important price when deciding about purchasing chosen food, including milk and dairy products, but the emphasis on quality is clearly rising. Consumers are focusing on quality, but they are looking for quality for the best price. Senadisai et al. (2014) also emphasize the price-quality ratio as the main motivating factor affecting the purchasing behavior of consumers of milk and dairy products in their research.

We found differences in the assessment of criteria influencing the choice of milk and dairy products among the respondents. Based on the Friedman test, it is possible to identify differences in factor evaluation confirmed by the statistical calculation of the p-value $(<0.0001)$, which is lower than the alpha significance level (0.05). Using Nemeny's method and based on the data, we conclude that quality is the most important criterion when choosing milk and dairy products (Group A), another group of significant factors is created by price, durability and composition (Group B), followed by a set of criteria created by the nutrition data and country of origin (Group C), the other group of factors consisted from the country of origin, the manufacturer and the package size (group D), and the last group of factors is the appearance of packaging and the promotion of the product (Group E). By dividing the factors determining consumer behavior when choosing milk and dairy products into these groups, it is possible to point to the differences in the assessment of individual criteria (groups) by consumers. The country of origin criterion is placed in two groups (Group C and Group D), which can be explained by the fact that there is no statistically significant difference in their ratings among Group $\mathrm{C}$ and Group D factors. However, between groups C and $\mathrm{D}$ there is a difference in the assessment of factors by consumers.

In the following part we will evaluate the factors, which are the key ones in terms of importance. The quality is the most important factor. Given the fact that price is the discussed criterion when choosing the milk and dairy products, we found out how consumers perceive their price. Based on the results, $57 \%$ of consumers consider price of milk and dairy products as reasonable and almost $40 \%$ consider these prices as high or very high, 


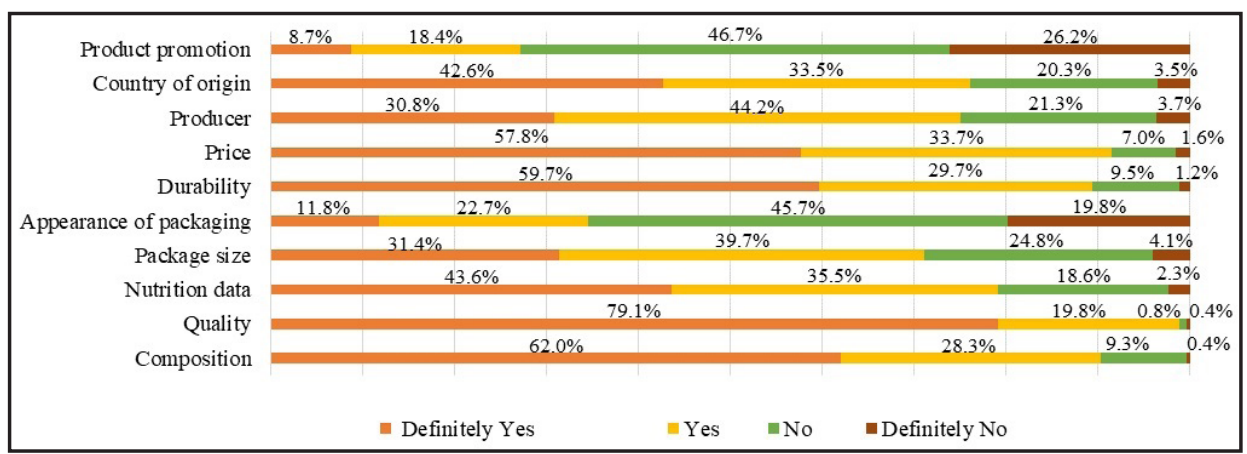

Source: Questionnaire survey, 2018

Figure 5: Importance of Individual Factors when Choosing Milk and Dairy Products.

which can be considered as one of the factors of low consumption of milk and dairy products. We also measured the average monthly expenditure on milk and dairy products per household member. The results showed that the largest number of consumers spend an average of 11-15 Eur (23.1 \%), 16-20 Eur (22.5\%) and 21-25 Eur $(15.5 \%)$ on milk and dairy products per month. In relation to this issue, we assumed that the average expenditure on milk and dairy products per household member depends on the total household income. On basis of applied Chisquare test for Independence, we can conclude that was proved the statistically significant dependence of expenditure on milk and dairy and household incomes ( $\mathrm{p}$-value $=0.027)($ Figure 6$)$. From the aspect of dependence tightness, there is a weak dependence demonstrated by the calculation of the Cramer coefficient (0.15).

The next criterion, which consumers consider important in choosing a particular dairy product, is the composition. Based on the results, it can be stated that consumers prefer semi-skimmed milk products $(37.6 \%)$ and whole milk products (28.1\%). Low-fat milk and dairy products are purchased by $12.6 \%$ of consumers, which suggests that respondents prefer low fat, mainly for health reasons, which do not allow them to consume fullfat products. In the context of this, it is important to note that $21.7 \%$ of respondents do not consider it necessary to look at the fat content of milk and dairy products and the other criteria are important for them. Krešić et al. (2010) emphasize that over $50 \%$ of consumers involved in their research are looking for low-fat dairy products. Preference for low-fat milk and dairy products may be due to the age and gender of respondents as well as to try to eat healthier (Hamilton et al., 2000).

The next important factor is the production process (Džupina and Cifranič, 2013). The results showed that consumers prefer durable dairy products
$(60.0 \%)$ characterized by a relatively long shelflife, a later date of consumption, a purchase in larger quantities and a subsequent lower purchasing frequency. This is confirmed by research by Bousbia et al. (2008), the results of which showed that consumers are the most commonly bought durable milk and dairy products. Fresh products are favored by almost $40 \%$ of respondents who are looking for products produced in traditional ways and are limited by shorter product durability.

The survey was also focused on the main reasons for consumption of milk and dairy products. The results showed (Figure 7) that milk is mainly consumed due to its taste $(50.0 \%)$, rational diet $(20.3 \%)$, high nutritional values (14.0\%) and addiction since childhood $(12.6 \% \%)$. Similar results have also been found by Alwis et al. (2009) and Kurajdová et al. (2015) who examined the factors influencing the consumption of milk and dairy products and found that the taste and the nutritional content is a stimulating motivation for consuming.

The aim of the survey aimed at milk and dairy producers and processors was to map out the situation in the Slovak dairy market with an emphasis on sales of milk and dairy products. We have identified, who are target customers, how they ensure product sales, what issues they are dealing with in sales.

The entities are mainly oriented to final consumers $(78.3 \%)$, as well as to the processing enterprises $(21.7 \%)$. In the case of the largest group of their customers, they mainly use direct sales from the yard $(61.1 \%)$, company stores $(38.9 \%)$, sales through the farmers' markets (33.3\%) and sales through distribution channels (55.6). $91.3 \%$ of the interviewed producers sell their products only on the Slovak market while $14.3 \%$ of them are not even able to sell the entire production. At present, $8.7 \%$ of surveyed subjects 


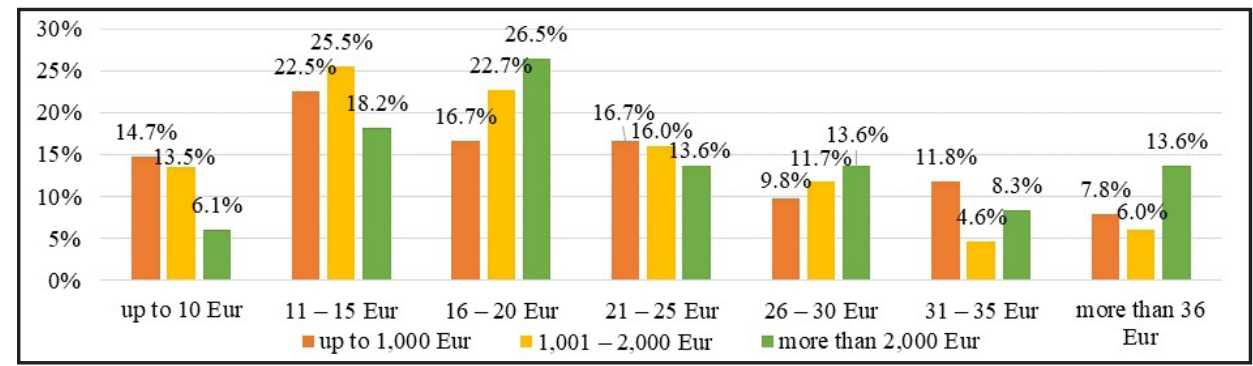

Source: Questionnaire survey, 2018

Figure 6: Average Monthly Expenditure on Milk and Dairy Products according to the Average Monthly Household Incomes.

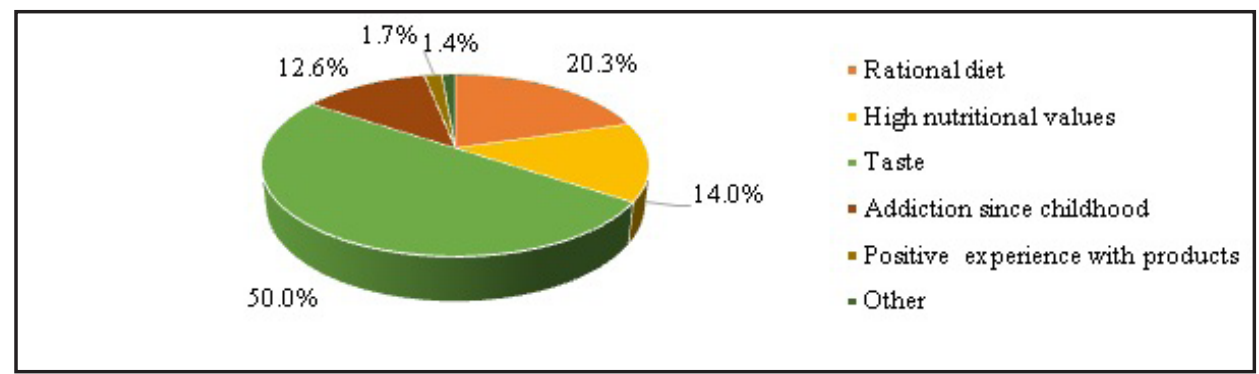

Source: Questionnaire survey, 2018

Figure 7: Reasons for Consuming of Milk and Dairy Products.

export their products to the foreign markets, especially to the Czech Republic, which ensures the realization of the entire quantity of produced production.

In the context of the analysis, it is important to note the change in the sales volume in the last 5 years. The results showed that $65.2 \%$ of business subjects experienced increased sales volumes as a result of a change in consumer behavior in the dairy market by focusing on local products and higher quality, increased promotion, or the introduction of new technologies and increased production volumes. $13 \%$ of surveyed producers had reduced sales of their products due to the high pressure of processing enterprises, and retail chains at low redemption prices accompanied by the reluctance of the producers to sell their products at liquidation price, the low purchasing power of demand, the offer of foreign substitute products sold on our market at lower price. $21.8 \%$ of the enterprises stated that the sales volume of their products had not changed in the last few years and remains at a constant level. Producers and processors focused on the sales problems, such as low milk prices and the pressure of the trade chains to low prices of milk and dairy products, lack of support for the sales, lack of consumption of selected products. Zdráhal et al. (2018) found out that foreign competition has negative impact on dairy firms.
In order to keep sales volume of milk and dairy products with a tendency for growth, businesses use different forms of promotion, especially flyers (39.1\%), web pages $34.8 \%$ and social networks $(34.8 \%)$. To address the situation on the dairy market, producers and processors have the possible suggestions in the form of higher support for domestic farmers by the state, creating of suitable conditions for business entities, reduction of imports of milk and dairy products, or sales support for the Slovak dairy products with an appeal to increase the consumption of milk and dairy products. Vasylieva (2017) found out that reducing retail prices and raising solvency of population would be the option for supporting the food industry, as well as effectively using quite big amount of public subsidies from the Rural Development Programme (Špička, 2015).

\section{Conclusion}

An analysis of milk and dairy consumption shows that there has been a significant change in nutrition in recent years. The paper was orientated on the main factors determining the demand for milk and dairy products. Consumer behavior was identified on basis of a consumer survey, the results of which showed regular purchases and consumption of milk and dairy products. We found out, that the most common places to buy 
are supermarkets and hypermarkets and that the quality, price, composition, shelf life and nutrient content are the main factors determining the choice of the monitored food. The results show that Slovak consumers prefer whole milk and semi-skimmed milk and dairy products and are looking for durable dairy products. Consumers consume selected foods because of their appetite and nutrients. We expect that a rational way of life will be preferred by consumers in the future and will influence the consumption of milk and dairy products. Therefore, we also examined the future of dairy industry from the point of view of producers and processors. We have identified the main problems associated with sales of selected food in Slovakia, which are manifested mainly in the low redemption price of milk, the pressure of the trade chains to low prices of milk and dairy products, consumers' orientation towards cheaper foreign dairy products, the lack of support for the sales of quality Slovak dairy products and deepening the consumer's lack of consumption of milk and dairy products. We propose to increase the support for domestic farmers and sales support for the Slovak milk by the state in the form of intensified projects with an appeal to increase consumption. Implementing these measures into practice in the dairy sector could be a tool for maintaining the dairy industry in Slovakia with a perspective for the future.

\section{Acknowledgements}

The work was supported by the Slovak Research and Development Agency on the basis of Contract No. APVV-16-0244 "Qualitative factors affecting the production and consumption of milk and cheese".

Corresponding authors

Lubica Kubicová

Department of Marketing and Trade, Faculty of Economics and Management

Slovak University of Agriculture in Nitra, Tr. A. Hlinku 2, 94976 Nitra, Slovakia

E-mail: kubicova.lubka@gmail.com

\section{References}

[1] Alwis, A., Edirisinghe, J. and Athauda, A. (2009) "Analysis of Factors Affecting Fresh Milk Consumption Among the Mid-Country Consumers”, Tropical Agricultural Research and Extension, Vol. 12, No. 2, pp. 103-109. ISSN 1391-3646. DOI 10.4038/tare.v12i2.2799.

[2] Bousbia, A., Boudalia, S., Chelia, S., Oudaifia, K., Amari, H., Benidir, M., Belkheir, B. and Hamzaoui, S. (2017) "Analysis of Factors Affecting Consumer Behavior of Dairy Products in Algeria: A Case Study from the Region of Guelma”, International Journal of Agricultural Research, Vol. 12, No. 2 , pp. 93 - 101. ISSN 1816-4897. DOI 10.3923/ijar.2017.93.101.

[3] Cecchini, L., Torquati, B. and Chiorri, M. (2018) "Sustainable agri-food products: A review of consumer preference studies through experimental economics", Agricultural Economics (AGRICECON), Vol. 64, No. 12, pp. 554-565. ISSN 0139-570X. DOI 10.17221/272/2017-AGRICECON.

[4] Ćuzović, S., Sokolov Mladenović, S. and Ćuzović, D. (2017) „Impact of Retail Formats on the Development of Food Retailing“, Entrepreneurial Business and Economics Review, Vol. 5, No. 1, pp. 11-26. ISSN 2353-8821. DOI 10.15678/EBER.2017.050101.

[5] Džupina, M. and Cifranič, M. (2013) "The philosophy of CSR as a means for collaboration of firms with state and public administration", Journal of Innovations and Applied Statistics, Vol. 3, No. 2, pp. 11-18. ISSN 1338-5224.

[6] Fogarassy, C., Nguyen, H. H., Olah, J. and Popp, J. (2018) „Transition management applications to accelerate sustainable food consumption - comparative analysis between Switzerland and Hungary“, Journal of International Studies, Vol. 11, No. 3, pp. 31-43. E-ISSN 2306-3483, ISSN 2071-8330. DOI 10.14254/2071-8330.2018/11-3/3.

[7] GFK (2017) “Ako sa meni slovenský spotrebitel", GFK, June 2017. [Online]. Available: https:/www.gfk.com/sk/insights/tlacove-spravy/ako-sa-meni-slovensky-spotrebitel/ [Accessed: 14 June 2017]. 
[8] Hamilton, J., Knox, B., Hill, D. and Parr, H. (2000) "Reduced fat products - Consumer perceptions and preferences", British Food Journal, Vol. 102, No. 7, pp. 494-506. ISSN 0007-070X. DOI 10.1108/00070700010336454.

[9] Horská, E., Nagyová, L., Stávková, J., Turčínková, J., Stejskal, L., Bolaños, R. M., Araque Padilla, R. A., Montero Simó, M. J., Ramírez Sobrino, J. N., Matysik-Pejas, R. and Szafrańska, M. (2009) "Európsky spotrebitel' a spotrebitel'ské správanie" (In Slovak), Nitra, Slovenská pol'nohospodárska univerzita v Nitre, 219 p. ISBN 978-80-5520-318-8.

[10] Kapsdorferová, Z. and Nagyová, L. (2005) "Consumer behavior at the Slovak dairy market. Spotrebitel'ské správanie na slovenskom trhu mlieka a mliečnych výrobkov“ (in Slovak), Agricultural Economics (AGRICECON), Vol. 51, No. 8, pp. 362-368. ISSN 1805-9295. DOI 10.17221/5120-AGRICECON.

[11] Košičiarová, I., Nagyová, L'. and Holienčinová, M. (2017) “Consumer behaviour on Slovak yoghurt and fermented milk products market", Acta Universitatis Agriculturae et Silviculturae Mendelianae Brunensis, Vol. 65, No. 6, pp. 1967-1978. ISSN 2464-8310. DOI 10.11118/actaun201765061967.

[12] Krešić, G., Herceg, Z., Lelas, V. and Režek Jambrak, A. (2010) “Consumers' behaviour and motives for selection of dairy beverages in Kvarner region: a pilot study", Mljekarstvo, Vol. 60, No. 1, pp. 50 - 58. ISSN 1846-4025.

[13] Kubelaková, A. and Šugrová, M. (2017) "Habit or choice? The decision - making process of young generation in purchasing dairy products in the Slovak Republic", International Day of Science 2017 - economics, management, innovation, Moravian University Olomouc, pp. 113-120. ISBN 978-80-7455-060-7.

[14] Kubicová, L. and Dobák, D. (2012) "Vývoj a úroveň spotreby mlieka a mliečnych výrobkov v SR a modelovanie dopytu po potravinách vo vybraných skupinách domácností" (In Slovak), Slovakian Agriculturtal University in Nitra, p. 88. ISBN 978-80-552-0821-3.

[15] Kubicová, L'. and Habánová, M. (2012) “Development of milk consumption and marketing analysis of its demand", Potravinárstvo, Vol. 6, No. 4, pp. 66-72. ISSN 1337-0960. DOI 10.5219/236.

[16] Kumar, A. and Babu, S. (2014) "Factors Influencing Consumer Buying Behavior with Special Reference to Dairy Products in Pondicherry State", International Monthly Refereed Journal of Research in Management and Technology, Vol. 3, No. 1, pp. 65-73. ISSN 2320-0073.

[17] Kurajdová, K., Táborecká-Petrovičová, J. and Kaščḱková, A. (2015) "Factors influencing milk consumption and purchase behavior - evidence from Slovakia", Procedia Economics and Finance, Vol. 34, No. 1, pp. 573-580. ISSN 2212-5671. DOI 10.1016/S2212-5671(15)01670-6.

[18] Mach, J., Dvořák, M. and Hošková, P. (2018) "EU Milk and Dairy Market Changes and Impact of Globalisation Trends" (In Czech), Globalization and its socio-economic consequences", Part III.- Economic Progress in Post-Soviet Countries. 10.10.2018, Rajecke Teplice, Slovakia; Zilina, Slovakia: University of Zilina, pp. 1204-1212. ISSN 2454-0943.

[19] Matejková, E., Pietriková, M. and Poláková, Z. (2013) "Praktikum zo štatistiky A" (In Slovak), Slovenská pol'nohospodárska univerzita v Nitre, p. 200. ISBN 978-80-552-1050-6.

[20] Matošková, D. and Gálik, J. (2016) “Trh s mliekom a mliečnymi výrobkami a jeho prognóza do roku 2020”, Ekonomika polnohospodárstva, Vol. 16, No. 2, pp. 44-62. ISSN 1335-6186.

[21] Namiotko, V. and Baležentis, T. (2017) „Dynamic Efficiency under Investment Spikes in Lithuanian Cereal and Dairy Farms, Economics and Sociology, Vol. 10, No. 2, pp. 33-46. ISSN 2071-789X. DOI 10.14254/2071-789X.2017/10-2/3.

[22] Nagyová, L., Holienčinová, M., Košičiarová, I. and Holota, T. (2016) "Corporate social responsibility in food manufacturing companies - environmental dimensions", Acta Universitatis Agriculturae et Silviculturae Mendelianae Brunensis. Vol. 64, No.3, pp. 1037-1043. ISSN 1211-8516. DOI 10.11118/actaun201664031037. 
[23] Nicklas, T. A., O'Neil, C. E. and Fulgoni, V. L. (2009) "The role of dairy in meeting the recommendations for shortfall nutrients in the American diet", The Journal of the American College of Nutrition, Vol. 28, No. 1, pp. 73-81. ISSN 0731-5724. DOI 10.1080/07315724.2009.10719807.

[24] Polakevičová, I. (2015) "Application of transactional analysis in marketing research - models of the hierarchy of effects of marketing communication and structural analysis", Prohuman, Vol. 7, No. 2, pp. 167-173. ISSN 1338-1415.

[25] Senadisai, P., Trimetsoontorn, J. and Fongswan, W. (2014) "Model of Factors Influencing the Intention to Purchase Lactose-free Milk for the Population of Bankok", Research Journal of Business Management, Vol. 8, No. 3, pp. 284-293. ISSN 2152-0437. DOI 10.3923/rjbm.2014.284.293.

[26] Śmigielska, G. and Stefańska, M. (2017) „Innovative Positioning as a Marketing Tool of Retailers on the Food Market", Entrepreneurial Business and Economics Review, Vol. 5, No. 1, pp. 77-90. ISSN 2353-8821. DOI 10.15678/EBER.2017.050105.

[27] Smutka,L., Svatoš, M., Tomšík, K. and Sergienko,O. I. (2016) "Foreign trade in agricultural products in the Czech Republic", Agricultural Economics (AGRICECON), Vol. 62, No. 1, pp. 9-25. ISSN 0139-570X. DOI 10.17221/18/2015-AGRICECON.

[28] Statistical Office of the Slovak Republic. (2018) "Databases". Statistical Office of the Slovak Republic, Dec. 2018. [Online]. Available: https://slovak.statistics.sk/wps/portal/ ext/Databases [Accessed: 6 Dec. 2018].

[29] Stehlíková, B. (2005) “Neparametrické štatistické metódy“, Nitra, Slovenská polnohospodárska univerzita in Nitra, p. 63. ISBN 80-8069-496-6. (In Slovak)

[30] Špička, J. (2015) "The Efficiency Improvement of Central European Corporate Milk Processors in 2008 - 2013", AGRIS on-line Papers in Economics and Informatics, Vol. 7, No. 4, pp. 175-188. ISSN 1804-1930. DOI 10.7160/aol.2015.070417.

[31] The Dairy Council (2016) "Milk", The Dairy Council, Jan. 2016. [Online]. Available: https://www. milk.co.uk/hcp/wp-content/uploads/sites/2/woocommerce_uploads/2016/12/Milk_consumer_2016. pdf [Accessed: 01 Jan. 2016].

[32] Vasylieva, V. (2017) "Economic Aspects of Food Security in Ukrainian Meat and Milk Clusters", AGRIS on-line Papers in Economics and Informatics, Vol. 9, No. 3, pp. 81-92. ISSN 1804-1930. DOI 10.7160/aol.2017.090308.

[33] Zdráhal, I., Chmelíková, G. and Blažková, I. (2018) "Sector-Wide and Country-Specific Drivers of Firm Performance in the Visegrad Group Dairy Industry", AGRIS on-line Papers in Economics and Informatics, Vol. 10, No. 4, pp. 89-100. ISSN 1804-1930. DOI 10.7160/aol.2018.100410. 